\title{
Pharmacological Characterization of $5-\mathrm{HT}_{1 \mathrm{~A}}$ Autoreceptor-Coupled GIRK Channels in Rat Dorsal Raphe 5-HT Neurons
}

\author{
Alberto Montalbano, Renato Corradetti, Boris Mlinar* \\ Department of Neuroscience, Psychology, Drug Research and Child Health, University of Florence, \\ Florence, Italy \\ * bmlinar@unifi.it
}

\section{Abstract}

G protein-activated inwardly rectifying potassium (GIRK) channels in 5-HT neurons are assumed to be principal effectors of 5-hydroxytryptamine $1 \mathrm{~A}\left(5-\mathrm{HT}_{1 \mathrm{~A}}\right)$ autoreceptors, but their pharmacology, subunit composition and the role in regulation of 5-HT neuron activity have not been fully elucidated. We sought for a pharmacological tool for assessing the func-

\section{G openaccess}

Citation: Montalbano A, Corradetti R, Mlinar B (2015) Pharmacological Characterization of 5- $\mathrm{HT}_{1 \mathrm{~A}}$ Autoreceptor-Coupled GIRK Channels in Rat Dorsal Raphe 5-HT Neurons. PLoS ONE 10(10): e0140369. doi:10.1371/journal.pone. 0140369

Editor: Steven Barnes, Dalhousie University, CANADA

Received: July 23, 2015

Accepted: September 24, 2015

Published: October 13, 2015

Copyright: @ 2015 Montalbano et al. This is an open access article distributed under the terms of the Creative Commons Attribution License, which permits unrestricted use, distribution, and reproduction in any medium, provided the original author and source are credited.

Data Availability Statement: All relevant data are within the paper.

Funding: Funding for this study was provided by the University of Florence. A. Montalbano was recipient of a fellowship from the Regione Toscana and Aziende Chimiche Riunite Angelini Francesco A.C.R. A.F. SpA (POR CRO FSE 2007-2013: 5HT@DRUGeMOOD).

Competing Interests: The authors have declared that no competing interests exist. tional role of GIRK channels in 5-HT neurons by characterizing the effects of drugs known to block GIRK channels in the submicromolar range of concentrations. Whole-cell voltageclamp recording in brainstem slices were used to determine concentration-response relationships for the selected GIRK channel blockers on 5- $\mathrm{HT}_{1 \mathrm{~A}}$ autoreceptor-activated inwardly rectifying $\mathrm{K}^{+}$conductance in rat dorsal raphe $5-\mathrm{HT}$ neurons. 5- $\mathrm{HT}_{1 \mathrm{~A}}$ autoreceptoractivated GIRK conductance was completely blocked by the nonselective inwardly rectifying potassium channels blocker $\mathrm{Ba}^{2+}\left(\mathrm{EC}_{50}=9.4 \mu \mathrm{M}\right.$, full block with $\left.100 \mu \mathrm{M}\right)$ and by SCH23390 $\left(E_{50}=1.95 \mu \mathrm{M}\right.$, full block with $\left.30 \mu \mathrm{M}\right)$. GIRK-specific blocker tertiapin-Q blocked 5- $\mathrm{HT}_{1 \mathrm{~A}}$ autoreceptor-activated GIRK conductance with high potency $\left(\mathrm{EC}_{50}=33.6\right.$ $\mathrm{nM}$ ), but incompletely, i.e. 16\% of total conductance resulted to be tertiapin-Q-resistant. $\mathrm{U} 73343$ and $\mathrm{SCH} 28080$, reported to block GIRK channels with submicromolar $\mathrm{EC}_{50} \mathrm{~S}$, were essentially ineffective in 5-HT neurons. Our data show that inwardly rectifying $\mathrm{K}^{+}$channels coupled to $5-\mathrm{HT}_{1 \mathrm{~A}}$ autoreceptors display pharmacological properties generally expected for neuronal GIRK channels, but different from GIRK1-GIRK2 heteromers, the predominant form of brain GIRK channels. Distinct pharmacological properties of GIRK channels in 5-HT neurons should be explored for the development of new therapeutic agents for mood disorders.

\section{Introduction}

It is well documented that the activity of raphe 5-HT neurons is under regulatory control by $5-\mathrm{HT}_{1 \mathrm{~A}}$ autoreceptors and $\mathrm{K}^{+}$channels. Early electrophysiological studies in vivo [1] and in midbrain slices [2] suggested that stimulation of 5-HT receptors hyperpolarize dorsal raphe 
5-HT neurons by an increase in $\mathrm{K}^{+}$conductance. Using intracellular recordings, Williams et al. [3] showed that stimulation of 5-HT or $\mathrm{GABA}_{\mathrm{B}}$ receptors on dorsal raphe 5-HT neurons activates an inwardly rectifying $\mathrm{K}^{+}$conductance via a pertussis toxin sensitive G-protein. This conductance was abolished by low $(100 \mu \mathrm{M})$ concentration of $\mathrm{Ba}^{2+}$. Studies using whole-cell [4] and single-channel [5] patch-clamp recording on acutely isolated dorsal raphe 5-HT neurons confirmed the sensitivity to pertussis toxin and the block by $\mathrm{Ba}^{2+}$. These studies further revealed that the receptor implicated belongs to the $5-\mathrm{HT}_{1 \mathrm{~A}}$ subtype and that the activation of $\mathrm{K}^{+}$channels occurs via a direct membrane-limited pathway without the involvement of soluble intracellular messengers. Similar findings were reported by Bayliss et al. [6] for 5-HT neurons in the medulla oblongata (raphe pallidus and raphe obscurus). Together, these studies clearly indicate that the inwardly rectifying $\mathrm{K}^{+}$channel activated by $5-\mathrm{HT}_{1 \mathrm{~A}}$ autoreceptors belongs to the GIRK $\left(\mathrm{K}_{\mathrm{ir}} 3\right)$ channel family. Consistently, it has been shown that GIRK1 $\left(\mathrm{K}_{\mathrm{ir}} 3.1\right)$, GIRK2 $\left(\mathrm{K}_{\mathrm{ir}} 3.2\right)$ and GIRK3 $\left(\mathrm{K}_{\mathrm{ir}} 3.3\right)$ mRNA and proteins are expressed in dorsal raphe 5-HT neurons [7-10].

In raphe 5-HT neurons, the activation of $5-\mathrm{HT}_{1 \mathrm{~A}}$ autoreceptors, besides the opening of GIRK channels, also produces an inhibition of voltage-gated $\mathrm{Ca}^{2+}$ channels [11-13] and, probably, modulate other ion channel types [3,4]. The precise role of GIRK channels in the control of 5-HT neuron activity has remained unclear, in part due to the limited knowledge of their pharmacological properties. $\mathrm{Ba}^{2+}$, a nonselective blocker of inwardly rectifying $\mathrm{K}^{+}$channels, is the only drug so far reported to block GIRK channels in raphe 5-HT neurons, albeit with unknown $\mathrm{EC}_{50}$. Given the functionally important role of $5-\mathrm{HT}_{1 \mathrm{~A}}$ autoreceptor-activated inwardly rectifying $\mathrm{K}^{+}$channels in the control of 5-HT neuron activity, the availability of organic blockers would greately help further functional studies and may lead to the development of valuable new therapeutic agents. Here, we used whole-cell recording in brainstem slices to characterize the effects of available GIRK channel blockers on inwardly rectifying $\mathrm{K}^{+}$ current activated by $5-\mathrm{HT}_{1 \mathrm{~A}}$ autoreceptors in $5-\mathrm{HT}$ neurons. We found that inwardly rectifying $\mathrm{K}^{+}$channels coupled to $5-\mathrm{HT}_{1 \mathrm{~A}}$ autoreceptors have pharmacological properties generally expected from GIRK channels, although the profile of blocker sensitivity differs from that of GIRK1-GIRK2 heteromers, the predominant form of brain GIRK channels.

\section{Materials and Methods}

\section{Animal Welfare and Ethical Statement}

All animal care and experimental procedures complied with the European Communities Council Directive (2010/63/UE) and were approved by the Internal Committee for Animal Care and Experimental Use (IACUC) of the University of Florence and communicated to the Italian Ministry of Health, as required (D.L. 116/92). A total of 22 male Wistar rats (Harlan Italy, Milano, Italy) were used in the present study. Animals were housed under standard laboratory conditions $\left(12 \mathrm{~h} \mathrm{light} / \mathrm{dark}\right.$ cycle, ambient temperature $22 \pm 1^{\circ} \mathrm{C}$, humidity $40-50 \%$, standard chow and water ad libitum). Animals (25-35 days of age at the experimental day) were sacrified under isoflurane anesthesia, and all efforts were made to minimize suffering.

\section{Whole-cell patch-clamp recordings}

Experimental procedures have been previously described in detail [14]. In brief, the brain was rapidly removed and dissected in ice-cold gassed $\left(95 \% \mathrm{O}_{2}\right.$ and $\left.5 \% \mathrm{CO}_{2}\right)$ artificial cerebrospinal fluid (ACSF) composed of: $124 \mathrm{mM} \mathrm{NaCl}, 2.75 \mathrm{mM} \mathrm{KCl}, 1.25 \mathrm{mM} \mathrm{NaH}_{2} \mathrm{PO}_{4}, 1.3 \mathrm{mM} \mathrm{MgCl}$, $2 \mathrm{mM} \mathrm{CaCl}_{2}, 26 \mathrm{mM} \mathrm{NaHCO}_{3}, 11 \mathrm{mM} \mathrm{D}$-glucose. The brainstem was sliced coronally into $200 \mu \mathrm{m}$ thick slices with a vibratome (DSK, T1000, Dosaka, Japan). After recovery for at least $90 \mathrm{~min}$ at room temperature, the slices were individually transferred to the recording chamber 
and superfused continuously with warmed $\left(29-31^{\circ} \mathrm{C}\right.$; Warner Instruments in-line heater TC324-C), modified (see below) ACSF at a rate of $2 \mathrm{~mL} \mathrm{~min}^{-1}$. Slices were allowed to equilibrate for at least $15 \mathrm{~min}$ before the beginning of the recording. Drugs were bath-applied through a peristaltic pump-driven perfusion system and a complete exchange of the recording chamber volume occurred in approximately $1 \mathrm{~min}$. Neurons within the dorsal raphe nucleus were visualized by infrared differential interference contrast (IR-DIC) video microscopy with a Newicon camera (C2400-07; Hamamatsu, Hamamatsu City, Japan) mounted on an upright microscope (Axioskop; Zeiss, Göttingen, Germany). Recordings were made using an EPC-10 amplifier (HEKA Elektronic, Lamberecht, Germany). Patch pipettes were prepared from thick-walled borosilicate glass on a P-97 Brown-Flaming electrode puller (Sutter Instruments, Novato, CA, USA). The pipette solution consisted of: $120 \mathrm{mM}$ K gluconate, $15 \mathrm{mM} \mathrm{KCl}, 2 \mathrm{mM}$ $\mathrm{MgCl}_{2}, 10 \mathrm{mM}$ HEPES, $0.1 \mathrm{mM}$ EGTA, $10 \mathrm{mM} \mathrm{Na} \mathrm{N}_{2}$ phosphocreatine, $4 \mathrm{mM} \mathrm{MgATP}, 0.3 \mathrm{mM}$ $\mathrm{Na}_{3} \mathrm{GTP}$ (pH 7.35 with $\approx 9 \mathrm{mM} \mathrm{KOH}$ ). Pipettes had filled-tip resistance of 2.5-5.2 M 2 .

To block synaptic transmission, all recordings were done using modified ACSF supplemented with a cocktail of glutamate and GABA/glycine receptor blockers consisting of: $10 \mu \mathrm{M}$ NBQX (2,3-dioxo-6-nitro-1,2,3,4-tetrahydrobenzo[f] quinoxaline-7-sulfonamide disodium salt), $20 \mu \mathrm{M}$ D-AP5 (D-(-)-2-amino-5-phosphonopentanoic acid), $10 \mathrm{mM}$ strychnine hydrochloride, $10 \mu \mathrm{M}$ SR-95531 (6-imino-3-(4-methoxyphenyl)-1(6H)-pyridazinebutanoic acid hydrobromide) and $2 \mu \mathrm{M}$ CGP-55845 (3-N[1-(S)-(3,4-dichlorophenyl)ethyl]amino-2-(S)hydroxypropyl-P-benzyl-phosphinic acid hydrochloride). The modified ACSF also contained $5.5 \mathrm{mM} \mathrm{K}^{+}$(the additional $2.75 \mathrm{mM} \mathrm{by} \mathrm{Na}^{+}$substitution) to increase the driving force for inward $\mathrm{K}^{+}$current and to shift $\mathrm{K}^{+}$reversal potential to a more positive value, thus permitting reliable detection of inwardly rectifying $\mathrm{K}^{+}$currents at membrane potentials more negative than $-85 \mathrm{mV}$, at which there is a neglibile contribution of outward rectifying $\mathrm{K}+$ currents and voltage-gated ion channels. We used hyperpolarizing voltage ramps from the holding potential of $-65 \mathrm{mV}$ (to $-125 \mathrm{mV}$, every $10 \mathrm{~s} ; 100 \mathrm{mV} \mathrm{s}^{-1} ; 3 \mathrm{kHz}$ cutoff frequency low-pass filter; $10 \mathrm{kHz}$ sampling frequency) and measured the conductance from the slope of inward $\mathrm{K}^{+}$current in range from - 110 to $-90 \mathrm{mV}\left(\mathrm{G}_{-110 /-90 \mathrm{mV}}\right)$. To monitor access resistance throughout the recording, hyperpolarizing pulses ( $10 \mathrm{mV} ; 100 \mathrm{~ms}$ duration; $16 \mathrm{kHz}$ low-pass filter; $25 \mathrm{kHz}$ sampling frequency; cell capacitance cancellation circuit switched off) were interlaced with ramps. The access resistance was in 8 to $25 \mathrm{M} \Omega$ range and recordings were interrupted when it changed for more than $25 \%$. In addition, approximately $15 \%$ of the experiments were aborted since they were compromised by spontaneous activation of a marked outward rectifying $\mathrm{K}^{+}$current, similar to that previously described by Bayliss et al. [6], which was not further examined. The membrane potential was not corrected for Donnan liquid junction potential. The effects of channel blockers were examined using a cumulative concentration-response protocol in the contunuous presence of the 5- $\mathrm{HT}_{1 \mathrm{~A}}$ receptor agonist 5-carboxamidotryptamine maleate (5-CT). One experiment was performed per slice. Each concentration of blocker was bath-applied until the apparent steady-state of the online monitored $\mathrm{G}_{-110 /-90}$ values was reached, i.e. typically eight to ten minutes, with the exception of SCH23390 (up to $20 \mathrm{~min}$ ). In most of recordings three to five increasing concentrations of a blocker were succesfully applied and the concentrationresponse relationship in individual neurons could be fitted by the four parameters logistic equation $\mathrm{y}=\mathrm{b}+(\mathrm{a}-\mathrm{b}) /\left(1+\left(\mathrm{EC}_{50} /[\text { Blocker }]\right)^{\mathrm{nH}}\right)$, where $a$ corresponds to $\mathrm{G}_{-110 /-90}$ in the absence of blocker effect, $b$ corresponds to $\mathrm{G}_{-110 /-90}$ with the maximal blocker effect, $\mathrm{EC}_{50}$ is the half-maximally effective concentration and $\mathrm{n}_{\mathrm{H}}$ is the Hill coefficient. 


\section{Materials}

Stock solutions of 5-CT, $\mathrm{BaCl}_{2}$, tertiapin-Q, SCH23390 [(R)-(+)-7-Chloro-8-hydroxy3-methyl-1-phenyl-2,3,4,5-tetrahydro-1H-3-benzazepine hydrochloride] were prepared in water and those of SCH28080 (2-Methyl-8-(phenylmethoxy)imidazo[1,2-a]pyridine-3-acetonitrile) and U73343 (1-[6-[[(17 $\beta)$-3-Methoxyestra-1,3,5(10)-trien-17-yl]amino]hexyl]2,5-pyrrolidinedione) in DMSO. All stock solutions, which were at least a thousand times the highest experimental concentration, were aliquoted and stored at $-20^{\circ} \mathrm{C}$ until use. The highest experimental concentration of DMSO was 0.05\%. 5-CT, SCH23390 and U73343 were purchased from Tocris (Tocris Bioscience, Bristol, UK); SCH28080 from HelloBio (Bristol, UK); CGP-55845; D-AP5, SR-95531, NBQX from Abcam (Cambridge, U.K.); tertiapin-Q from Abcam and Tocris; Isoflurane from Baxter S.p.A. (Rome, Italy); HEPES, ATP and DMSO from Fluka (St. Gallen, Switzerland). All other substances were obtained from Sigma-Aldrich (Milano, Italy)

\section{Data analysis and statistical procedures}

Data were analyzed using Patchmaster 2 (HEKA Elektronic) and then with Prism 6 software (GraphPad Software, San Diego, CA, USA). All statistics are given as mean \pm SD, except $\mathrm{EC}_{50}$ values which are given as mean and 95\% confidence intervals (95\% C.I.).

\section{Results}

To activate 5- $\mathrm{HT}_{1 \mathrm{~A}}$ autoreceptors in dorsal raphe 5-HT neurons, we used 5-CT, an agonist which in our experimental conditions selectively activates $5-\mathrm{HT}_{1 \mathrm{~A}}$ autoreceptors $[15,14]$ and is structurally similar to the endogenous agonist, 5-HT. As shown in Fig 1A-1C, bath application of 5-CT produced a concentration-dependent increase in an inwardly rectifying $\mathrm{K}^{+}$conductance which was completely reversed upon agonist washout. To minimize $5-\mathrm{HT}_{1 \mathrm{~A}}$ receptor and GIRK channel desensitization we used 5-CT at $30 \mathrm{nM}$, a concentration which produces near-maximal effect. As shown in Fig 1D-1F, at this concentration only a limited run-down of the response was observed over a prolonged period of continuous agonist application $(22.3 \pm 4.1 \%$ in $1 \mathrm{~h}$, mean $\pm \mathrm{SD}, n=6)$, permitting a fairly accurate determination of concentration-response relationships for the investigated blockers in individual neurons.

We first wanted to characterize the antagonism of $5-\mathrm{HT}_{1 \mathrm{~A}}$ receptor-activated inwardly rectifying $\mathrm{K}^{+}$conductance by $\mathrm{Ba}^{2+}$, an information surprisingly missing even if $\mathrm{Ba}^{2+}$ is the only blocker so far reported to be effective in 5-HT neurons. As shown in Fig 2, $\mathrm{Ba}^{2+}$ concentrationdependently blocked 5-CT-induced inwardly rectifying $\mathrm{K}^{+}$conductance, producing full block at $100 \mu \mathrm{M}$ concentration. The full block by $\mathrm{Ba}^{2+}$ was confirmed in additional recordings in which 5-CT (30 nM, $10 \mathrm{~min}$ ) failed to induce inwardly rectifying $\mathrm{K}^{+}$conductance when coapplied in the presence of $100-150 \mu \mathrm{M} \mathrm{Ba}^{2+}$ (10 min; $n=5$, not shown). In four individual neurons in which $\mathrm{Ba}^{2+}$ was applied in concentrations from 3 to $100 \mu \mathrm{M}$, fit of data with a logistic equation revealed $\mathrm{EC}_{50}$ values ranging from 5.1 to $17.3 \mathrm{nM}$ and Hill slope values ranging from -1.06 to -1.39 (Fig $2 \mathrm{E}$ and $2 \mathrm{~F}$ ). Concentration-response relationship of $\mathrm{Ba}^{2+}$ on pooled data (Fig $2 \mathrm{G}$ ) revealed an $\mathrm{EC}_{50}$ of $9.4 \mu \mathrm{M}(95 \%$ C.I. 7.2 to $12.2 \mu \mathrm{M})$ and a Hill Slope of -1.21 (95\% C. I. -0.83 to -1.59$)$.

We next characterized the block of $5-\mathrm{HT}_{1 \mathrm{~A}}$ receptor-activated inwardly rectifying $\mathrm{K}^{+}$conductance by the specific GIRK blocker tertiapin-Q, a non-air-oxidizable derivative of honey bee toxin tertiapin [16]. Tertiapin-Q concentration-dependently blocked 5-CT-induced inwardly rectifying $\mathrm{K}^{+}$conductance in the submicromolar range, but the block was incomplete (e.g. Fig 3A and 3B). To better examine if tertiapin-Q can produce a complete block, in an additional set of experiments, tertiapin-Q was applied only at concentrations of $1 \mu \mathrm{M}(n=2)$ and/ 
A
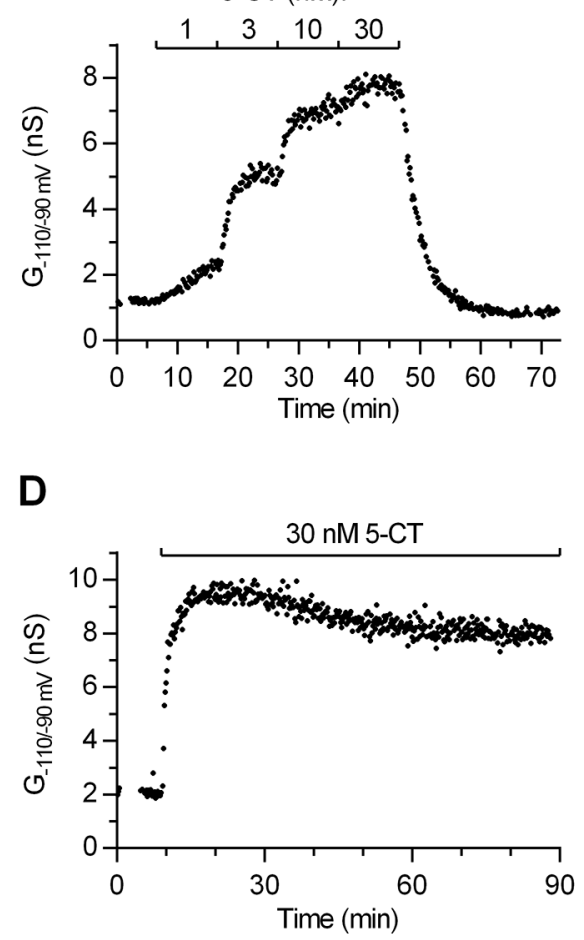

B

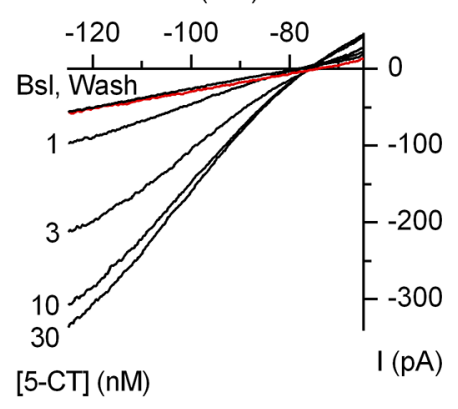

E

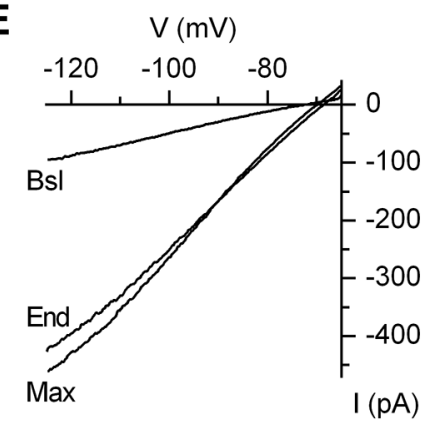

C

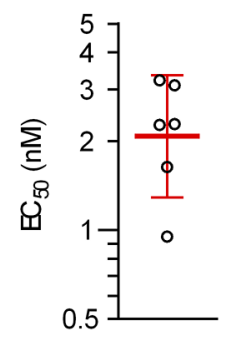

F

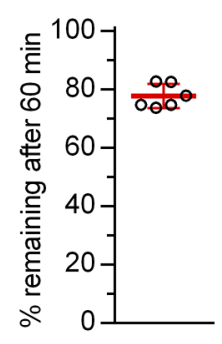

Fig 1. 5-CT-activated inwardly rectifying $\mathrm{K}^{+}$conductance in 5-HT neurons displays limited desensitization. (A) Time-course of a representative experiment $(n=6)$ showing the effect of increasing concentrations of bath applied 5- $\mathrm{HT}_{1 \mathrm{~A}}$ receptor agonist, 5 -CT on inwardly rectifying $\mathrm{K}^{+}$conductance ( $\mathrm{G}$. $110 /-90 \mathrm{mv}$ ) in a dorsal raphe 5-HT neuron. Extracellular solution contained $5.5 \mathrm{mM} \mathrm{K}^{+}$and a mix of synaptic blockers (see methods). In this and the following Figs, time indicates duration of whole-cell configuration. (B) Current-voltage plot of the same experiment. Traces are averages of the last 13 individual ramps recorded before 5-CT application (Bsl); at the indicated 5-CT concentrations and following the washout of 5-CT (Wash; red trace). (C) Scatter plot of EC 50 values of 5-CT in individual neurons. Bars correspond to geometric mean $\pm 95 \%$ C.I. (D) Time-course of a representative experiment $(n=6)$ showing persistent activation of $\mathrm{G}_{-110 /-90 \mathrm{mv}}$ by $30 \mathrm{nM} 5-\mathrm{CT}$. (E) Current-voltage plot of the same experiment. Traces are averages of 13 consecutive ramps recorded before 5-CT application (Bsl); during the maximal effect (Max) and at the end of the recording (End). (F) Scatter plot showing the percentage of maximal 5-CT effect $(\approx 10 \mathrm{~min}$ in $5-\mathrm{CT})$ remaining $60 \mathrm{~min}$ after reaching the maximum $(\approx 70 \mathrm{~min}$ in 5-CT) in individual recordings. Bars correspond to mean \pm SD.

doi:10.1371/journal.pone.0140369.g001

or $3 \mu \mathrm{M}(n=5$; e.g. Fig 3C and 3D). In all cases, tertiapin-Q failed to produce full block. In eight individual neurons in which tertiapin-Q was applied at concentrations from 10 or $30 \mathrm{nM}$ to 0.3 or $1 \mu \mathrm{M}$, fit of data with a logistic equation showed that tertiapin-Q blocked 5-CTinduced inwardly rectifying $\mathrm{K}^{+}$conductance with $\mathrm{EC}_{50}$ values ranging from 20.9 to $74.6 \mathrm{nM}$ and Hill slope values ranging from -0.76 to -1.60 (Fig $3 \mathrm{E}$ and $3 \mathrm{~F}$ ). Concentration-response of tertiapin-Q on pooled data from all fifteen experiments (Fig $3 \mathrm{G}$ ) revealed an $\mathrm{EC}_{50}$ of $33.6 \mathrm{nM}$ (95\% C.I. 27.8 to $40.7 \mathrm{nM}$ ), a Hill Slope of 1.22 (95\% C.I. -0.90 to -1.54 ) and a maximal block of $83.9 \%$ (95\% C.I. 79.6 to $88.3 \%$ ).

We proceeded to examine the block of 5- $\mathrm{HT}_{1 \mathrm{~A}}$ receptor-activated inwardly rectifying $\mathrm{K}^{+}$ conductance by organic compounds reported to block GIRK with $\mathrm{EC}_{50}$ values in the submicromolar range. We first tested $\mathrm{SCH} 23390$, a classic dopamine $\mathrm{D}_{1}$ receptor antagonist and potent 5- $\mathrm{HT}_{2 \mathrm{C}}$ receptor agonist [17] which is also direct GIRK channel blocker [18]. As shown in Fig 4A-4C, SCH23390 concentration-dependently blocked 5-CT-induced inwardly rectifying $\mathrm{K}^{+}$ conductance, producing a complete block at $30 \mu \mathrm{M}$ concentration. The ability of SCH 23390 to fully block 5 -CT-induced inwardly rectifying $\mathrm{K}^{+}$conductance was confirmed in additional recordings in which it was applied only at $30 \mu \mathrm{M}(n=3$; Fig $4 \mathrm{D}-4 \mathrm{~F})$ and in recordings in which $5-\mathrm{CT}(30 \mathrm{nM}, 10 \mathrm{~min})$ failed to induce inwardly rectifying $\mathrm{K}^{+}$conductance when coapplied in the presence of $30 \mu \mathrm{M} \mathrm{SCH} 23390$ (20 min; $n=3$, not shown). In eight individual 
A

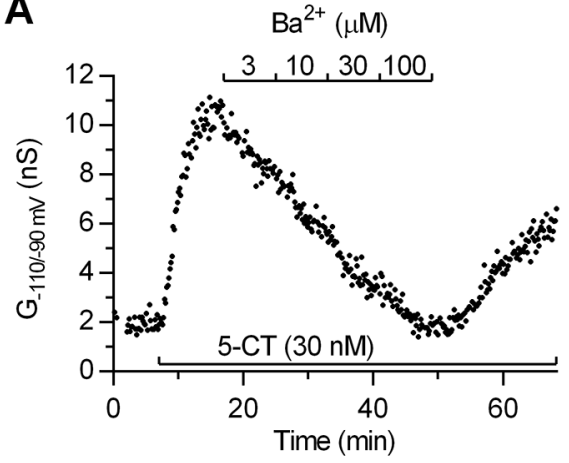

C

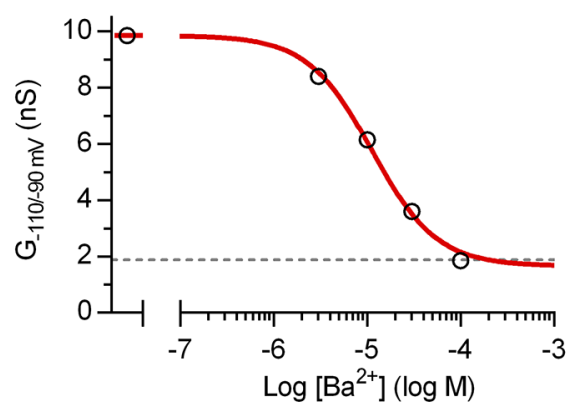

B $\quad \mathrm{V}(\mathrm{mV})$

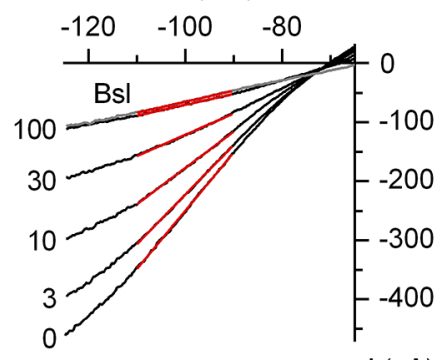

$\left[\mathrm{Ba}^{2+}\right](\mu \mathrm{M})$
$\mathrm{I}(\mathrm{pA})$

D

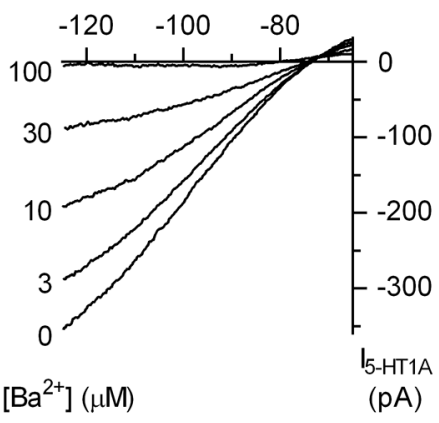

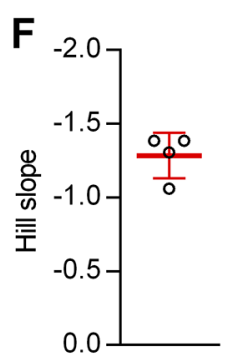

G

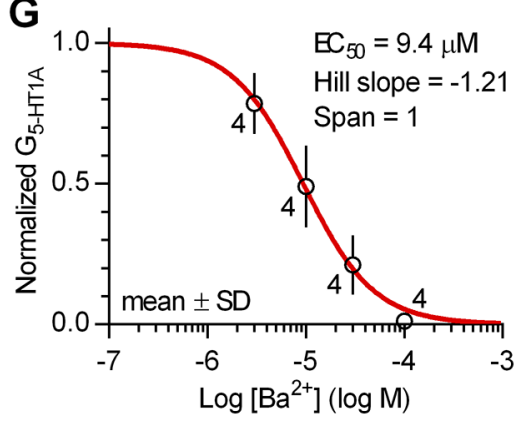

Fig 2. Block of $5-\mathrm{HT}_{1 \mathrm{~A}}$ autoreceptor-activated inwardly rectifying $\mathrm{K}^{+}$conductance by $\mathrm{Ba}^{2+}$. (A-D) Representative experiment. (A) Time-course of a representative experiment $(n=4)$ illustrating the concentration-dependent block of 5-CT-induced inwardly rectifying $\mathrm{K}^{+}$conductance $\left(\mathrm{G}_{-110 /-90 \mathrm{mv}}\right)$ by $\mathrm{Ba}^{2+}$. (B) Current-voltage plot of the same experiment. Traces are averages of the last 7 individual ramps recorded before 5-CT application (Bsl; grey trace) and at the indicated concentrations of $\mathrm{Ba}^{2+}$. Red lines represent linear fits of data from -110 to $-90 \mathrm{mV}$ used to compute $\mathrm{G}_{-110 /-90 \mathrm{mv}}$. (C) Graph illustrating calculation of $\mathrm{Ba}^{2+}$ concentration-response curve in individual recordings. Symbols correspond to the slope of the respective red lines shown in B. Dashed line represents the baseline slope. The red curve is the data fit with the function $\mathrm{y}=\mathrm{b}+(\mathrm{a}-\mathrm{b}) /\left(1+\left(\mathrm{EC}_{50} /\left[\mathrm{Ba}^{2+}\right]\right)^{\mathrm{nH}}\right)$, where $a$ corresponds to the slope conductance in the absence of $\mathrm{Ba}^{2+}, b$ corresponds to the maximal $\mathrm{Ba}^{2+}$ effect, $\mathrm{EC}_{50}$ is the half-maximally effective $\mathrm{Ba}^{2+}$ concentration and $\mathrm{n}_{H}$ is the Hill coefficient. (D) Current-voltage plot of net $5-C T$-induced current $\left(I_{5-H T 1 A}\right)$ obtained by subtraction of the baseline current (gray trace in $\mathrm{B}$ ). (E) Scatter plot of $\mathrm{EC}_{50}$ values of $\mathrm{Ba}^{2+}$ in individual neurons. Bars correspond to geometric mean $\pm 95 \%$ C.I. (F) Scatter plot of Hill slope values of $\mathrm{Ba}^{2+}$ in individual recordings. Bars correspond to mean $\pm \mathrm{SD}$. (G) Average concentration-response for $\mathrm{Ba}^{2+}$ on normalized data from all experiments. Data are normalized from zero (BsI) to one (5-CT with zero $\mathrm{Ba}^{2+}$ ) and thus correspond to net $5-\mathrm{HT}_{1 \mathrm{~A}}$ receptor-activated inwardly rectifying $\mathrm{K}^{+}$conductance $\left(\mathrm{G}_{5-\mathrm{HT} 1 \mathrm{~A}}\right)$. Red line is the best least-squares fit to the logistic equation, $y=1 /\left(1+\left(E_{50} /\left[\mathrm{Ba}^{2+}\right]\right)^{\mathrm{nH}}\right)$, where $\mathrm{EC}_{50}$ is the half-maximally effective concentration and $n_{H}$ is the Hill coefficient $\left(R^{2}=0.894\right)$.

doi:10.1371/journal.pone.0140369.g002 
A

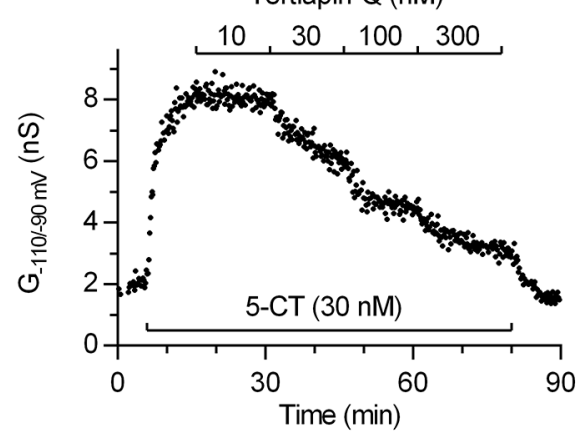

B

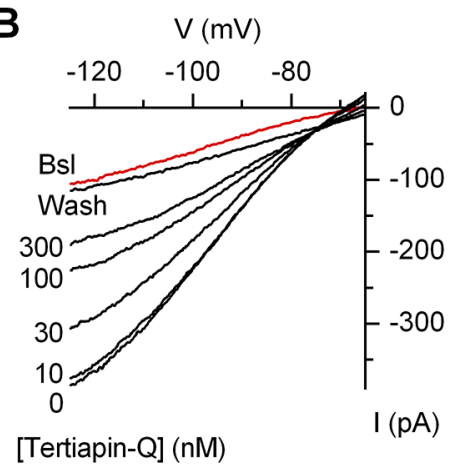

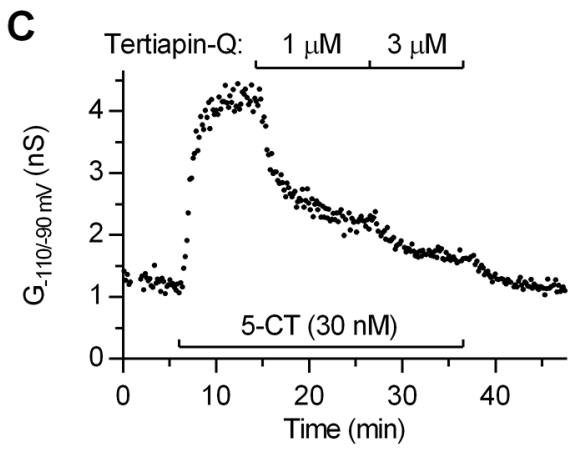
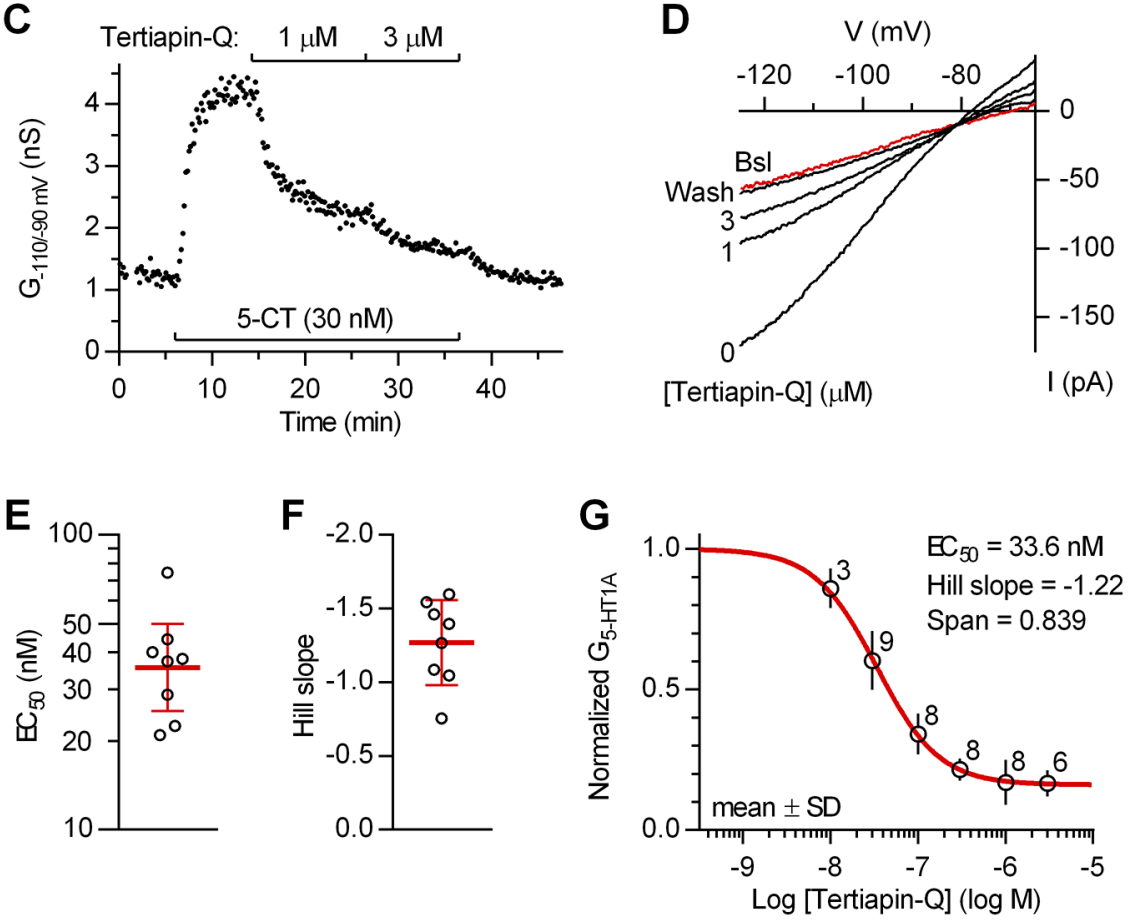

Fig 3. Block of $5-\mathrm{HT}_{1 \mathrm{~A}}$ autoreceptor-activated inwardly rectifying $\mathrm{K}^{+}$conductance by tertiapin-Q. (A) Time-course of a representative experiment $(n=8)$ illustrating concentration-dependent block of 5-CTinduced inwardly rectifying $\mathrm{K}^{+}$conductance $\left(\mathrm{G}_{-110 /-90 \mathrm{mv}}\right)$ by tertiapin-Q. (B) Current-voltage plot of the same experiment. Traces are averages of the last 7 individual ramps recorded before 5-CT application (Bsl; red trace), at the indicated concentrations of tertiapin- $\mathrm{Q}$, and following the washout of 5-CT and tertiapin- $\mathrm{Q}$ (Wash). (C) Time-course of a representative experiment $(n=7)$ illustrating incomplete block of 5-CT-induced inwardly rectifying $\mathrm{K}^{+}$conductance by high concentrations of tertiapin-Q. (D) Current-voltage plot of the same experiment. Traces are averages of the last 11 individual ramps recorded before 5-CT application (Bsl; red trace), at the indicated concentrations of tertiapin- $Q$, and following the washout of 5-CT and tertiapin- $Q$ (Wash). (E) Scatter plot of $E_{50}$ values of tertiapin- $Q$ in individual neurons. Bars correspond to geometric mean $\pm 95 \%$ C.I. (F) Scatter plot of Hill slope values of tertiapin-Q in individual recordings. Bars correspond to mean $\pm S D$. (G) Average concentration-response for tertiapin-Q on normalized data corresponding to net $5-\mathrm{HT}_{1 \mathrm{~A}}$ receptor-activated inwardly rectifying $\mathrm{K}^{+}$conductance $\left(\mathrm{G}_{5-\mathrm{HT} 1 \mathrm{~A}}\right)$ from all experiments. Red line is the best least-squares fit to the logistic equation, $y=b+(1-b) /\left(1+\left(E C_{50} /[\text { Tertiapin- } Q]\right)^{n H}\right)$, where $E C_{50}$ is the half-maximally effective concentration, $n_{H}$ is the Hill coefficient, and $b$ is the fraction remaining at the maximal tertiapin-Q effect $\left(R^{2}=0.906\right)$.

doi:10.1371/journal.pone.0140369.g003

neurons in which SCH23390 was cumulatively applied at concentrations ranging from 1 to 10 or $30 \mu \mathrm{M}$, fit of data with logistic equation revealed a block of 5-CT-induced inwardly 
A

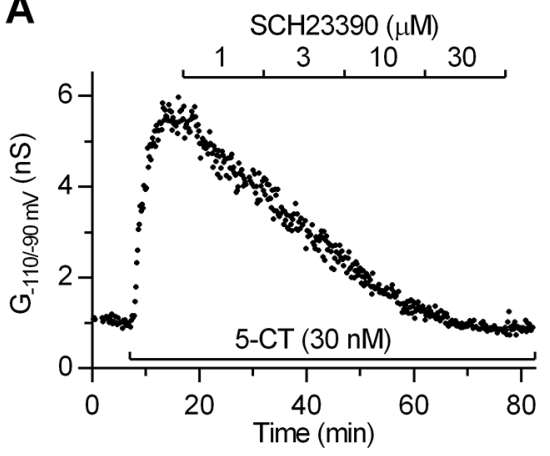

D

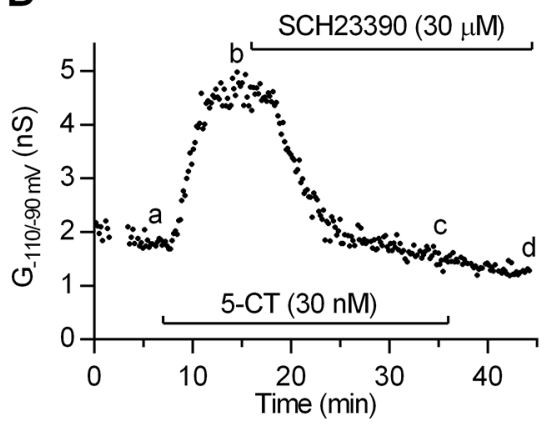

B

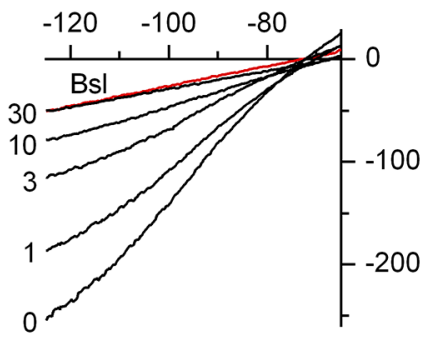

$[\mathrm{SCH} 23390](\mu \mathrm{M})$
C

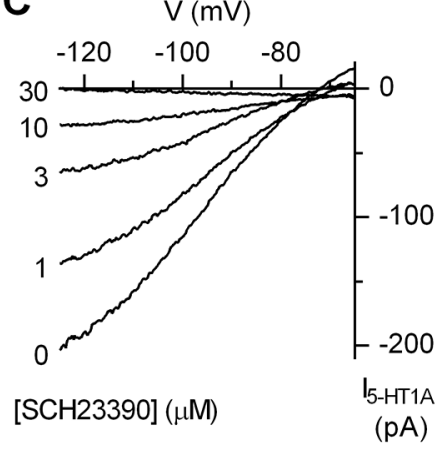

F

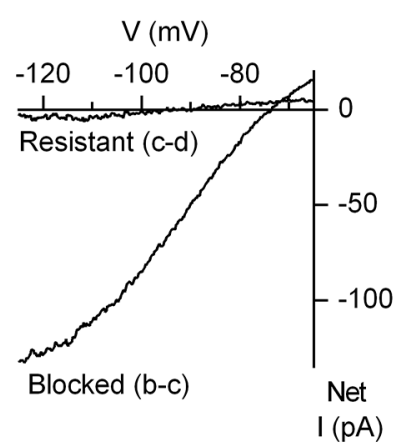

G

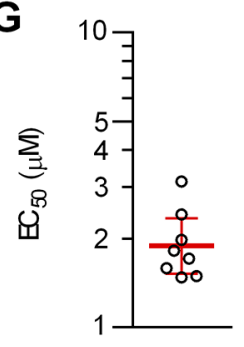

H

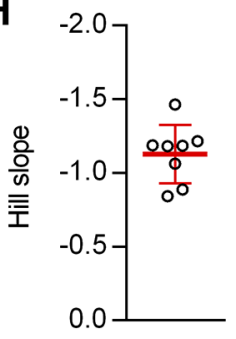

E

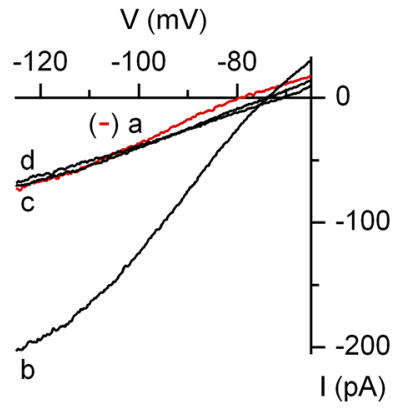

\section{I}

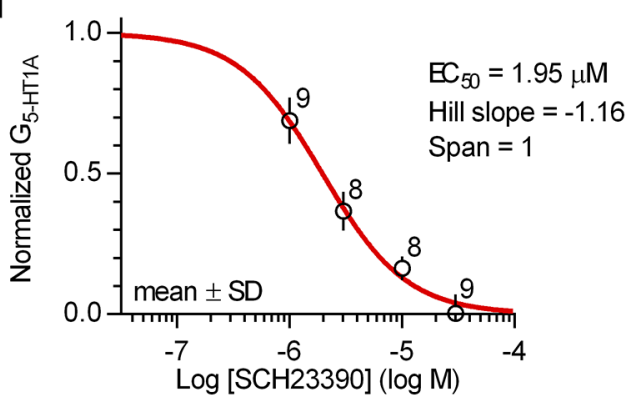

Fig 4. Block of 5-HT 1 autoreceptor-activated inwardly rectifying $\mathrm{K}^{+}$conductance by $\mathrm{SCH} 23390$. (A) Time-course of a representative experiment $(n=8)$ illustrating concentration-dependent block of 5-CT-induced inwardly rectifying $\mathrm{K}^{+}$conductance $\left(\mathrm{G}_{-110 /-90} \mathrm{mv}\right)$ by SCH23390. (B) Current-voltage plot of the same experiment. Traces are averages of the last 7 individual ramps recorded before 5-CT application (Bsl; red trace) and at the indicated concentrations of SCH23390. (C) Current-voltage plot of net 5-CT-induced current ( $\mathrm{I}_{5-\mathrm{HT} 1 \mathrm{~A}}$ ) obtained by subtraction of the baseline current (red trace in B). (D) Time-course of a representative experiment $(n=3)$ illustrating near complete block of 5 -CT-induced inwardly rectifying $\mathrm{K}^{+}$conductance by $30 \mu \mathrm{M} \mathrm{SCH} 23390$. (E) The current-voltage plot of the same experiment. Traces are averages of 11 individual ramps recorded before (a; red trace) and after (b) 5-CT application, after the application of SCH23390 (c) and following the washout of 5-CT (d). (F) Current-voltage plot of net SCH23390-blocked and SCH23390-resistant current of the same experiment. (G) Scatter plot of $\mathrm{EC}_{50}$ values of $\mathrm{SCH} 23390$ in individual recordings. Bars correspond to geometric mean $\pm 95 \% \mathrm{C}$.I. (F) Scatter plot of Hill slope values of $\mathrm{SCH} 23390$ in individual recordings. Bars correspond to mean $\pm \mathrm{SD}$. (G) Average concentration-response for SCH23390 on normalized data corresponding to net $5-\mathrm{HT}_{1 \mathrm{~A}}$ receptor-activated inwardly rectifying $\mathrm{K}^{+}$conductance $\left(\mathrm{G}_{5-\mathrm{HT} 1 \mathrm{~A}}\right)$ from all experiments. Red line is the best least-squares fit to the logistic equation, $y=1 /\left(1+\left(E_{50} /[S C H 23390]\right)^{n H}\right)$, where $E_{50}$ is the half-maximally effective concentration and $n_{H}$ is the Hill coefficient $\left(R^{2}=0.936\right)$.

doi:10.1371/journal.pone.0140369.g004

rectifying $\mathrm{K}^{+}$conductance with $\mathrm{EC}_{50}$ values ranging from 1.5 to $3.1 \mu \mathrm{M}$ and Hill slope values ranging from -0.84 to 1.47 (Fig $4 \mathrm{G}$ and $4 \mathrm{H}$ ). Concentration-response of $\mathrm{SCH}-23390$ on pooled data from all experiments (Fig 4I) revealed an $\mathrm{EC}_{50}$ of $1.95 \mu \mathrm{M}(95 \%$ C.I. 1.7 to $2.2 \mu \mathrm{M})$ and a Hill Slope of -1.16 (95\% C.I. -0.98 to -1.35). 
A
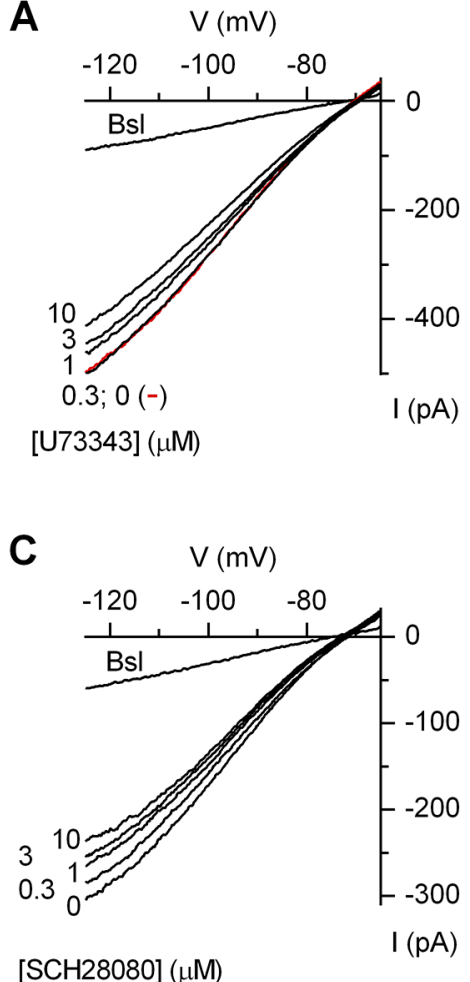

B
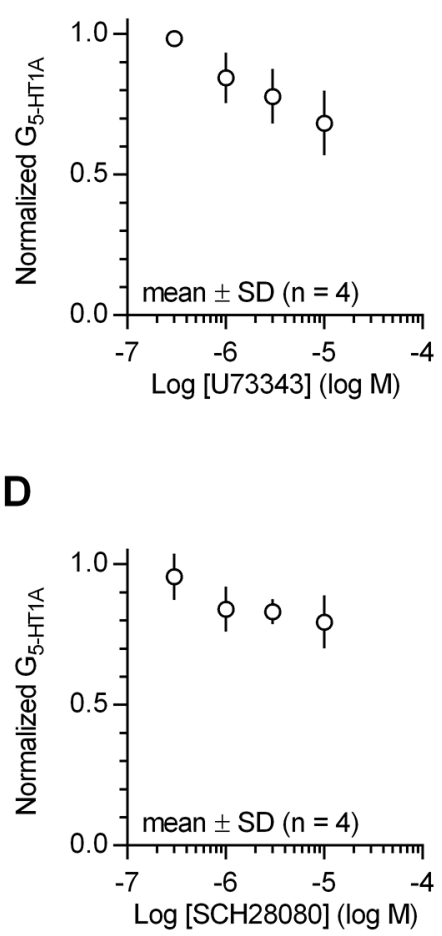

Fig 5. U73343 and $\mathrm{SCH} 28080$ are relatively ineffective blockers of $5-\mathrm{HT}_{1 \mathrm{~A}}$ autoreceptor-coupled inwardly rectifying $\mathrm{K}^{+}$channels. (A) Current-voltage plot of a representative experiment $(n=4)$ illustrating weak block of 5-CT-induced inwardly rectifying $\mathrm{K}^{+}$conductance by increasing concentrations of U73343. Each concentration was applied for $10 \mathrm{~min}$. Traces are averages of the last 7 individual ramps recorded before (Bsl) and after 5-CT application (0; red trace), and at the indicated concentrations of U73343. (B) Average concentration-response for $\mathrm{U} 73343$ on normalized data corresponding to net $5-\mathrm{HT}_{1 \mathrm{~A}}$ receptoractivated inwardly rectifying $\mathrm{K}^{+}$conductance $\left(\mathrm{G}_{5-\mathrm{HT} 1 \mathrm{~A}}\right)$ from all experiments. $(\mathrm{C})$ Current-voltage plot of a representative experiment $(n=4)$ illustrating the effect of increasing concentrations of SCH28080 on 5-CTinduced inwardly rectifying $\mathrm{K}^{+}$conductance. Each concentration was applied for $10 \mathrm{~min}$. Traces are averages of the last 7 individual ramps recorded before 5-CT application (Bsl) and at the indicated concentrations of $\mathrm{SCH} 28080$. (D) Average concentration-response for $\mathrm{SCH} 28080$ on normalized data from all experiments.

doi:10.1371/journal.pone.0140369.g005

We also examined the effect of two small molecules reported to block GIRK channels with $\mathrm{EC}_{50}$ values in the submicromolar range: U73343, which blocks GIRK channels in acutely isolated rat neocortical pyramidal cells with an $\mathrm{EC}_{50}$ of $400 \mathrm{nM}$ [19], and SCH28080, reported to block mouse GIRK channels in AtT20 and HL-1 cells with EC F0 $_{5}$ values of 200 and $300 \mathrm{nM}$, respectively [20]. As shown in Fig 5, both substances were poorly effective blockers of the 5-CT-induced inwardly rectifying $\mathrm{K}^{+}$conductance in the dorsal raphe 5-HT neurons. At $10 \mu \mathrm{M}$, the highest concentration tested, U73343 and SCH28080 reduced 5-CT-induced inwardly rectifying $\mathrm{K}^{+}$conductance by $31.6 \%$ (range $22.4-48.0 \%, n=4$ ) and $20.5 \%$ (range $12.3-$ $32.3 \%, n=4)$, respectively.

\section{Discussion}

Pharmacological properties of GIRK channels in 5-HT neurons have remained uncharacterized in spite of the evidence that GIRK channels are principal effectors of 5- $\mathrm{HT}_{1 \mathrm{~A}}$ autoreceptors. We attempted to find a blocker which may serve as a tool to study the role of GIRK channels in the regulation of 5-HT neuron activity. Whole-cell recording in brainstem slices were used to directly measure GIRK conductance. 
We report the first quantitative assessment of the effects of a series of specific organic blockers and $\mathrm{Ba}^{2+}$ on native inwardly rectifying $\mathrm{K}^{+}$channels activated by $5-\mathrm{HT}_{1 \mathrm{~A}}$ autoreceptor stimulation in raphe 5-HT neurons.

\section{Methodological considerations}

Pharmacology of neuronal GIRK channels is largely unexplored mostly because of the paucity of GIRK blockers available. In many neuronal types, e.g. pyramidal and Purkinje neurons, studies of GIRK channels by using whole-cell recordings can be additionally complicated by the combination of dendritic localization of GIRK channels and the low cell membrane input resistance. Raphe 5-HT neurons are suitable for studying GIRK channels since (i) their dendrites are relatively short and without extensive arborization and (ii) they are electrically compact, displaying high input resistance $(\geq 1 \mathrm{G} \Omega)$ in whole-cell patch-clamp recordings in brainstem slice preparation. Importantly, we found that when GIRK channels are continuously activated by a concentration of 5- $\mathrm{HT}_{1 \mathrm{~A}}$ receptor agonist which produces near-complete receptor stimulation, recorded whole-cell GIRK conductances display only slow and limited rundown, presumably caused by desensitization. This allows recordings of sufficient duration for a fairly accurate determination of the blocker's concentration-response relationship. Due to the run-down, the calculated $\mathrm{EC}_{50}$ and Hill slope values for the blockers are expectedly slightly under- and over-estimated, respectively. It is worth mentioning that when GIRK conductances in 5 -HT neurons are activated by supramaximal concentrations of $5-\mathrm{HT}_{1 \mathrm{~A}}$ receptor agonists (e.g. bath application of $300 \mathrm{nM} 5-\mathrm{CT}$ or R(+)-8-OH-DPAT) or with the inclusion of nonhydrolyzable GTP analogue GTP- $\gamma$-S in the pipette solution (100 $\mu \mathrm{M}$, instead of GTP) marked desensitization occurs ([6], our unpublished observation)

\section{Pharmacological properties of GIRK channels in 5-HT neurons only partially match those of GIRK1-GIRK2 heteromers}

In the brain, GIRK1, GIRK2 and GIRK3 channel subunits are widely expressed, whereas the GIRK4 subunit is found at low levels. Although the precise subunit composition of GIRK channels in various neuronal subtypes and subcellular compartments is not entirely known (for recent reviews see $[21,22]$ ), there is evidence that GIRK1-GIRK2 heteromer is the predominant form of GIRK channels in neurons [23] and that GIRK2-containing channels mediate postsynaptic inhibition by $G$ protein-coupled neurotransmitter receptors [24]. Neuronal GIRK channels may also be composed of different combinations of subunits, e.g. GIRK2A-GIRK2C [25], GIRK2-GIRK3 [26,27] and GIRK1-GIRK3 [28] and possibly of three different subunits [29]. All of these combinations are possible in 5-HT neurons, since they co-express GIRK1, GIRK2 and GIRK3 subunits [10].

Although the pharmacology of GIRK3-containing channels is still uncharacterized and subunit-selective GIRK blockers are presently lacking, some important conclusions regarding the molecular identity of GIRK channels in 5-HT neurons can be deduced from our findings. By comparing the effects of here characterized blockers with the published data on their activity at GIRK channels, it appears that $5-\mathrm{HT}_{1 \mathrm{~A}}$ receptor-activated inwardly rectifying $\mathrm{K}^{+}$conductance only partially matches that of GIRK1-GIRK2 heteromers. Relatively good correspondence was found for tertiapin- $\mathrm{Q}$ which blocked $5-\mathrm{HT}_{1 \mathrm{~A}}$ receptor-activated GIRK conductance with an $\mathrm{EC}_{50}$ of $\sim 34 \mathrm{nM}$, a value similar to those reported for blocking GIRK current in AtT-20 cells (102 nM; [20]) which express native mouse GIRK1 and GIRK2 subunits, and in HEK239 cells heterologously expressing mouse GIRK1 and GIRK2A or GIRK2C subunits ( $76 \%$ and $\sim 59 \%$ block by $100 \mathrm{nM}$, respectively; [30]). Similarly, the $\mathrm{EC}_{50}$ of SCH23390 $(\sim 2 \mu \mathrm{M})$ was in the range of those reported to block native mouse GIRK channels in AtT-20 cells $\left(\mathrm{EC}_{50}\right.$ of $\left.236 \mathrm{nM}\right)$ 
and heterologously expressed human GIRK1-GIRK2 channels (EC ${ }_{50}$ of $\left.7.8 \mu \mathrm{M}\right)$ [18]. In contrast, our finding that U73343 and SCH28080 are poorly effective blockers of GIRK channels in 5-HT neurons significantly differs from previous studies that showed that U73343 blocks native GIRK channels in rat neocortical pyramidal neurons and heterologously expressed GIRK1-GIRK2 channels with $\mathrm{EC}_{50}$ of $\sim 400 \mathrm{nM}(\sim 85 \%$ block by $10 \mu \mathrm{M})$ [19] and that SCH28080 blocks $\sim 80 \%$ of native mouse GIRK channels in AtT-20 cells with an $\mathrm{EC}_{50}$ of $\sim 200$ $\mathrm{nM}$ [20]. Finally, $\mathrm{Ba}^{2+}$ blocked $5-\mathrm{HT}_{1 \mathrm{~A}}$ receptor-activated GIRK channels with the $\mathrm{EC}_{50}$ of $9.4 \mu \mathrm{M}$, a value close to that of $12 \mu \mathrm{M}$ reported in rat CA3 pyramidal neurons, which express all GIRK subunits [31], but significantly lower than that reported for heterologously expressed mouse GIRK1-GIRK2 channels (EC 50 of $\sim 100 \mu \mathrm{M}$; [32]). Therefore, it seems unlikely that the 5- $\mathrm{HT}_{1 \mathrm{~A}}$ receptor-coupled GIRK channels in dorsal raphe 5-HT neurons is a GIRK1-GIRK2 heteromer. In addition, GIRK2 homomer may also be excluded as a $5-\mathrm{HT}_{1 \mathrm{~A}}$ autoreceptor effector since SCH23390 blocks heterologously expressed human GIRK2 homomer with the $\mathrm{EC}_{50}$ of $83 \mu \mathrm{M}$ [18], a value 40 times higher than in 5-HT neurons.

The conclusion that GIRK1-GIRK2 heteromer and GIRK2 homomer are unlikely to be $5-\mathrm{HT}_{1 \mathrm{~A}}$ autoreceptor-coupled channels in 5-HT neurons is further supported by expression studies that found a low level of GIRK2 mRNA and protein in rat dorsal raphe $[9,10]$ or failed to detect GIRK2 mRNA [7] and protein [8] at all. In addition, a recent functional study in mice in vivo [33], showed that genetic deletion of GIRK2 does not abolish $5-\mathrm{HT}_{1 \mathrm{~A}}$ receptor-mediated suppression of 5-HT neuron firing, but only results in a limited rightward shift of doseresponse curves for 8-OH-DPAT, a $5-\mathrm{HT}_{1 \mathrm{~A}}$ receptor agonist, and citalopram, a selective serotonin reuptake inhibitor (SSRI).

Although further studies are clearly needed to define the molecular identity of GIRK channels in 5-HT neurons, their distinct pharmacological properties might provide the foundation for the development of 5-HT neuron- selective/preferential GIRK blockers. Such drugs would have a potentially important therapeutic role since they should increase 5-HT neuron activity without causing serious side effects by the nonselective block of GIRK channels, in particular of neuronal GIRK1-GIRK2 and cardiac GIRK1-GIRK4 heteromers. In fact, the delay in the therapeutic effect of SSRIs, the most commonly prescribed antidepressants, has in part been ascribed to the drug-induced increase in raphe 5-HT level, which decreases 5-HT neuron activity by activating $5-\mathrm{HT}_{1 \mathrm{~A}}$ autoreceptors [34]. Thus, 5-HT neuron-specific GIRK blockers in association with SSRIs, may afford a valuable therapeutic strategy to hasten the antidepressant effects.

\section{Tertiapin-Q-resistant conductance}

The finding that $\sim 16 \%$ of total $5-\mathrm{HT}_{1 \mathrm{~A}}$ autoreceptor-activated inwardly rectifying $\mathrm{K}^{+}$conductance is tertiapin-Q-resistant was unexpected. The lack of a complete block is unlikely to be caused to impurities in tertiapin- $Q$ since identical results were observed with several different batches of tertiapin-Q obtained from two different commercial sources. We cannot exclude that part of the $5-\mathrm{HT}_{1 \mathrm{~A}}$ autoreceptor-activated tertiapin-Q-resistant conductance is mediated by ion channels other than GIRK, but this seems unlikely since $100 \mu \mathrm{M} \mathrm{Ba}^{2+}$ and $30 \mu \mathrm{M}$ SCH23390 produced full block. It is conceivable that a subpopulation of GIRK channels in 5-HT neurons has a distinctive GIRK subunit composition that results in tertiapin-Q-resistance. In fact, differential sensitivity of rat GIRK subunits to tertiapin- $Q$ has been demonstrated by Ramu et al. [35], who showed that high tertiapin-Q affinity of cardiac GIRK1-GIRK4 heteromers $\left(\mathrm{K}_{\mathrm{d}} \approx 13 \mathrm{nM},[16]\right)$ results from interaction of tertiapin-Q with GIRK4 subunit $\left(\mathrm{K}_{\mathrm{d}} \approx\right.$ $2 \mathrm{nM})$, while GIRK1 is relatively insensitive $\left(\mathrm{K}_{\mathrm{d}} \approx 20 \mu \mathrm{M}\right)$. Therefore, it is reasonable to assume that the tertiapin-Q-resistant conductance in $5-\mathrm{HT}$ neurons is mediated by a 
GIRK1-containing channels. Other subunits besides GIRK1 may contribute to differential sensitivity to tertiapin-Q. As example, Walsh [20] reported that tertiapin-Q blocks native mouse GIRK1-GIRK4 and GIRK1-GIRK2 channels with a two orders of magnitude different potency ( $\mathrm{EC}_{50}$ of 1.4 and $102 \mathrm{nM}$, respectively). Finally, tertiapin-Q-resistant channels may result from promiscuous GIRK1-IRK heteromerization, which has been demonstrated feasible by Ishihara et al.[36].

\section{Conclusions}

In conclusion, tertiapin-Q, SCH23390 and $\mathrm{Ba}^{2+}$ are useful tools for studying GIRK function in 5-HT neurons, albeit with specific limitations since tertiapin-Q does not produce full block whereas $\mathrm{SCH} 23390$ and $\mathrm{Ba}^{2+}$ do not warrant selectivity of action on GIRK channels. Importantly, our data show that $5-\mathrm{HT}_{1 \mathrm{~A}}$ autoreceptor-coupled GIRK channels in 5-HT neurons have specific pharmacological properties, which may provide foundation for the development of valuable new therapeutic agents.

\section{Author Contributions}

Conceived and designed the experiments: BM. Performed the experiments: AM BM. Analyzed the data: AM BM. Wrote the paper: RC BM.

\section{References}

1. Aghajanian GK, Vandermaelen $\mathrm{CP}$. Intracellular recordings from serotonergic dorsal raphe neurons: pacemaker potentials and the effect of LSD. Brain Res. 1982; 238: 463-469. PMID: 6284300

2. Aghajanian GK, Lakoski JM. Hyperpolarization of serotonergic neurons by serotonin and LSD: studies in brain slices showing increased $\mathrm{K}^{+}$conductance. Brain Res. 1984; 305: 181-185. PMID: 6331598

3. Williams JT, Colmers WF, Pan ZZ. Voltage- and ligand-activated inwardly rectifying currents in dorsal raphe neurons in vitro. J Neurosci. 1988; 8: 3499-3506. PMID: 3171686

4. Penington NJ, Kelly JS, Fox AP. Whole-cell recordings of inwardly rectifying $\mathrm{K}^{+}$currents activated by 5 $\mathrm{HT}_{1 \mathrm{~A}}$ receptors on dorsal raphe neurones of the adult rat. J Physiol. 1993; 469: 387-405. PMID: 8271204

5. Penington NJ, Kelly JS, Fox AP. Unitary properties of potassium channels activated by 5-HT in acutely isolated rat dorsal raphe neurones. J Physiol. 1993; 469: 407-426. PMID: 8271205

6. Bayliss DA, Li YW, Talley EM. Effects of serotonin on caudal raphe neurons: activation of an inwardly rectifying potassium conductance. J Neurophysiol. 1997; 77: 1349-1361. PMID: 9084602

7. Karschin C, Dissmann E, Stühmer W, Karschin A. IRK(1-3) and GIRK(1-4) inwardly rectifying $\mathrm{K}^{+}$channel mRNAs are differentially expressed in the adult rat brain. J Neurosci. 1996; 16: 3559-3570. PMID: 8642402

8. Murer G, Adelbrecht C, Lauritzen I, Lesage F, Lazdunski M, Agid Y, et al. An immunocytochemical study on the distribution of two G-protein-gated inward rectifier potassium channels (GIRK2 and GIRK4) in the adult rat brain. Neuroscience. 1997; 80: 345-357. PMID: 9284339

9. Fairchild G, Leitch MM, Ingram CD. Acute and chronic effects of corticosterone on 5-HT1A receptormediated autoinhibition in the rat dorsal raphe nucleus. Nuropharmacology. 2003; 45: 925-934.

10. del Burgo SL, Cortes R, Mengod G, Zarate J, Echevarria E, Salles J. Distribution and neurochemical characterization of neurons expressing GIRK channels in the rat brain. J Comp Neurol. 2008; 510 : 581-606. doi: 10.1002/cne.21810 PMID: 18698588

11. Penington NJ, Kelly JS. Serotonin receptor activation reduces calcium current in an acutely dissociated adult central neuron. Neuron 1990; 4: 751-758. PMID: 2140514

12. Penington NJ, Kelly JS, Fox AP. A study of the mechanism of $\mathrm{Ca}^{2+}$ current inhibition produced by serotonin in rat dorsal raphe neurons. J Neurosci. 1991; 11: 3594-3609. PMID: 1941097

13. Bayliss DA, Li YW, Talley EM. Effects of serotonin on caudal raphe neurons: inhibition of N- and P/Qtype calcium channels and the afterhyperpolarization. J Neurophysiol. 1997; 77: 1362-1374. PMID: 9084603 
14. Mlinar B, Montalbano A, Baccini G, Tatini F, Berlinguer Palmini R, Corradetti R. Nonexocytotic serotonin release tonically suppresses serotonergic neuron activity. J Gen Physiol. 2015; 145: 225-251. doi: 10.1085/jgp.201411330 PMID: 25712017

15. Audero E, Mlinar B, Baccini G, Skachokova ZK, Corradetti R, Gross C. Suppression of serotonin neuron firing increases aggression in mice. J Neurosci. 2103; 33: 8678-8688.

16. Jin W, Lu Z. Synthesis of a stable form of tertiapin: a high-affinity inhibitor for inward-rectifier $\mathrm{K}^{+}$channels. Biochemistry. 1999; 38: 14286-14293. PMID: 10572003

17. Millan MJ, Newman-Tancredi A, Quentric $Y$, Cussac D. The "selective" dopamine $D_{1}$ receptor antagonist, $\mathrm{SCH} 23390$, is a potent and high efficacy agonist at cloned human serotonin $\mathrm{C}_{\mathrm{C}}$ receptors. Psychopharmacology (Berl). 2001; 156 58-62.

18. Kuzhikandathil EV, Oxford GS. Classic D1 dopamine receptor antagonist R-(+)-7-chloro-8-hydroxy-3methyl-1-phenyl-2,3,4,5-tetrahydro-1H-3-benzazepine hydrochloride (SCH23390) directly inhibits G protein-coupled inwardly rectifying potassium channels. Mol Pharmacol. 2002; 62: 119-126. PMID: 12065762

19. Sickmann T, Klose A, Huth T, Alzheimer C. Unexpected suppression of neuronal G protein-activated, inwardly rectifying $\mathrm{K}^{+}$current by common phospholipase $\mathrm{C}$ inhibitor. Neurosci Lett. 2008; 436: 102106. doi: 10.1016/j.neulet.2008.02.067 PMID: 18358607

20. Walsh KB. Targeting GIRK Channels for the Development of New Therapeutic Agents. Front Pharmacol. 2011; 2: 64. doi: 10.3389/fphar.2011.00064 PMID: 22059075

21. Lüscher C, Slesinger PA. Emerging roles for G protein-gated inwardly rectifying potassium (GIRK) channels in health and disease. Nat Rev Neurosci. 2010; 11: 301-315. doi: 10.1038/nrn2834 PMID: 20389305

22. Luján R, Marron Fernandez de Velasco E, Aguado C, Wickman K. New insights into the therapeutic potential of Girk channels. Trends Neurosci. 2014; 37: 20-29 doi: 10.1016/j.tins.2013.10.006 PMID: 24268819

23. Liao $\mathrm{YJ}$, Jan $\mathrm{YN}$, Jan LY. Heteromultimerization of G-protein-gated inwardly rectifying $\mathrm{K}^{+}$channel proteins GIRK1 and GIRK2 and their altered expression in weaver brain. J Neurosci. 1996; 16: 71377150. PMID: 8929423

24. Lüscher C, Jan LY, Stoffel M, Malenka RC, Nicoll RA. G protein-coupled inwardly rectifying $\mathrm{K}^{+}$channels (GIRKs) mediate postsynaptic but not presynaptic transmitter actions in hippocampal neurons. Neuron 1997; 19: 687-695. PMID: 9331358

25. Inanobe A, Yoshimoto Y, Horio Y, Morishige KI, Hibino H, Matsumoto S, et al. Characterization of Gprotein-gated $\mathrm{K}^{+}$channels composed of Kir3.2 subunits in dopaminergic neurons of the substantia nigra. J Neurosci. 1999; 19: 1006-1017. PMID: 9920664

26. Jelacic TM, Kennedy ME, Wickman K, Clapham DE. Functional and biochemical evidence for G-protein-gated inwardly rectifying $\mathrm{K}^{+}$(GIRK) channels composed of GIRK2 and GIRK3. J Biol Chem. 2000; 275: 36211-36216. PMID: 10956667

27. Cruz HG, Ivanova $T$, Lunn ML, Stoffel M, Slesinger PA, Lüscher C. Bi-directional effects of GABAB receptor agonists on the mesolimbic dopamine system. Nat Neurosci. 2004; 7: 153-159. PMID: 14745451

28. Jelacic TM, Sims SM, Clapham DE. Functional expression and characterization of G-protein-gated inwardly rectifying $\mathrm{K}^{+}$channels containing GIRK3. J Membr Biol. 1999; 169: 123-129. PMID: 10341034

29. Aguado C, Colón J, Ciruela F, Schlaudraff F, Cabañero MJ, Perry C, et al. Cell type-specific subunit composition of G protein-gated potassium channels in the cerebellum. J Neurochem. 2008; 105: 497511. PMID: 18088366

30. Leaney JL. Contribution of Kir3.1, Kir3.2A and Kir3.2C subunits to native G protein-gated inwardly rectifying potassium currents in cultured hippocampal neurons. Eur J Neurosci. 2003; 18: 2110-2118. PMID: 14622172

31. Sodickson DL, Bean BP. GABA $A_{B}$ receptor-activated inwardly rectifying potassium current in dissociated hippocampal CA3 neurons. J Neurosci. 1996; 16: 6374-6385. PMID: 8815916

32. Velimirovic BM, Gordon EA, Lim NF, Navarro B, Clapham DE. The $\mathrm{K}^{+}$channel inward rectifier subunits form a channel similar to neuronal $G$ protein-gated $K^{+}$channel. FEBS Lett 1996; 379: 31-37. PMID: 8566224

33. Llamosas N, Bruzos-Cidón C, Rodríguez JJ, Ugedo L, Torrecilla M. Deletion of GIRK2 Subunit of GIRK Channels Alters the 5- $\mathrm{HT}_{1 \mathrm{~A}}$ Receptor-Mediated Signaling and Results in a Depression-Resistant Behavior. Int J Neuropsychopharmacol. 2015 doi: 10.1093/ijnp/pyv051

34. Artigas F, Romero L, de Montigny C, Blier P. Acceleration of the effect of selected antidepressant drugs in major depression by 5-HT1A antagonists. Trends Neurosci. 1996; 19: 378-383. PMID: 8873352 
35. Ramu Y, Klem AM, Lu Z. Short variable sequence acquired in evolution enables selective inhibition of various inward-rectifier $\mathrm{K}^{+}$channels. Biochemistry. 2004; 43: 10701-10709. PMID: 15311931

36. Ishihara K, Yamamoto $T$, Kubo Y. Heteromeric assembly of inward rectifier channel subunit Kir2.1 with Kir3.1 and with Kir3.4. Biochem Biophys Res Commun. 2009; 380: 832-837. doi: 10.1016/j.bbrc.2009. 01.179 PMID: 19338762 